\title{
Experimental model for evaluation of the cutaneous sensitivity of the abdomen ${ }^{1}$
}

\author{
Andreia Bufoni Farah ${ }^{2}$ \\ Fábio Xerfan Nahas ${ }^{3}$ \\ Élvio Bueno Garcia ${ }^{3}$ \\ Lydia Masako Ferreira ${ }^{4}$
}

Farah, AB, Nahas FX, Garcia EB, Ferreira LM. Experimental model for evaluation of the cutaneous sensitivity of the abdome. Acta Cir Bras [serial online] 2004 Vol 19 Special Edition. Available on URL: http://www.scielo.br/acb.

\begin{abstract}
The purpose of this study is to report an experimental model to evaluate several modalities of sensibility and to map the areas of the abdominal wall with decreased sensibility after abdominoplasty. Patients were divided in two groups: in the control group, patients had no previous abdominal incisions and patients of the experimental group had been undergone abdominoplasty. The sensibility evaluation of patients from the experimental group was made from 12 to 60 months after the operation. The abdominal skin was divided into twelve areas; nine of them were above the abdominoplasty incision and three below it. Sensibility to superficial touch, superficial pain, hot and cold temperature, vibration was tested and recorded as positive if the patient mentioned that he felt the stimulation or negative. Sensibility to pressure was tested with the use of different weights; therefore, a value was obtained when the patient felt the pressure. A specific test was used to evaluate each modality of sensibility. The experimental model designed to test skin sensibility after abdominoplasty showed to be feasible in patients.
\end{abstract}

KEY WORDS - Sensibility. Abdominoplasty. Abdominal wall.

${ }^{1}$ Study developed at the Laboratories of the Federal University of São Paulo - UNIFESP/EPM

Student of the Post-graduation Program in Plastic Surgery of the Federal University of São Paulo UNIFESP/EPM

PhD, Ínterim Professor, Plastic Surgery, Surgery Department of the Federal University of São Paulo UNIFESP/EPM

${ }^{4}$ MD, PhD, Titular and Head of the Plastic Surgery, Surgery Department of the Federal University of Sao Paulo - UNIFESP/EPM. 


\section{Introduction}

Abdominoplasty is a very common cosmetic procedure in the United States ${ }^{1}$. One of the undesirable consequences of this operation is the decrease of the sensibility of the abdominal skin. The anterior and lateral branches from the sixth to the twelfth intercostal nerves and branches of the nerves iliohypogastric and ilioinguinal supply sensation to the skin of the anterior abdomen 2,10 . The large undermining of the abdominal flap, during the abdominoplasty, severs several of these sensorial branches. One of the consequences of this surgery is the reduction of sensibility ${ }^{3,13}$. Many patients complain of the persistent reduction of sensitivity of the abdomen and may present trauma or burning because of the anesthesia of the flap ${ }^{7}$. The sensorial recovery of flaps has been evaluated with tactile and thermal tests of sensitivity and painful stimulation using a large number of methods $5,6,8,9,12,15$. Literature search showed only one study about the sensibility of the abdomen after abdominoplasty ${ }^{3}$.

When plastic surgeons inform their patients about the complications and outcome of abdominoplasty, they cannot warn them about the specific decrease of sensibility as well as the areas of the abdomen on which sensibility will change. Some patients complain and feel uncomfortable with these areas of hypoesthesia. They are more exposed to trauma and thermal injuries on the abdomen.

\section{Proposition}

The purpose of this study is to report the use of the method of evaluation of the skin sensibility to superficial touch, pain, pressure, vibration, and temperature, and map the sensibility of the abdominal skin after abdominoplasty.

\section{Method description}

Female patients were divided in two groups. The patients of the control group had no previous abdominal incisions. These patients were in good general health with no cutaneous or systemic condition that could affect the sensibility test. Patients of the experimental group had an abdominoplasty performed.

The sensibility evaluation was made from 12 to 60 months after abdominoplasty. These patients were divided into two groups of 10 patients each. In experimental group 1, patients were evaluated at 12 to 30 months postoperatively; patients in the group 2 were tested at 31 to 60 months postoperatively.

All the patients of the experimental group underwent abdominoplasty with standardized technique. All surgeries were performed under general anesthesia. A suprapubic incision extended laterally to the anterior iliac crest was performed. The abdominal cutaneous flap was dissected from the aponeurosis. The superior limit of this dissection was the costal margins and a level 2-cm below the xyphoid appendix. The external oblique perforators were not severed. The rectus diastasis was corrected with 2-0 Nylon on a two-layer suture: the first layer was made with interrupted buried stitches $0.4 \mathrm{~cm}$ from each other; the second layer was a continuous suture. The 
excess flap was resected and the circumcised umbilical stalk was pulled through the flap. The abdominal skin flap was then sutured to the supra pubic area.

\section{Sensibility Evaluation}

The same examiner tested all patients. The patient was evaluated on a quiet room, at a room temperature between 22 to $25^{\circ} \mathrm{C}$, on a supine position, over a comfortable bed and with the patient's eyes blinded by a shadow.

The abdomen was divided into twelve areas (FIGURE 1). On each area, six different sensorial tests were performed to evaluate superficial touch, superficial pain, pressure, vibration and hot and cold temperature.

\section{Pilot Plan}

A study was performed to evaluate the two-point discrimination in seven patients without previous abdominal incisions, to determine the dimension of the areas to be evaluated. The average value was $30 \mathrm{~mm}$. When the same test was applied to patients, who underwent abdominoplasty the average value was $75 \mathrm{~mm}$. Therefore the abdomen was divided into 12 areas.

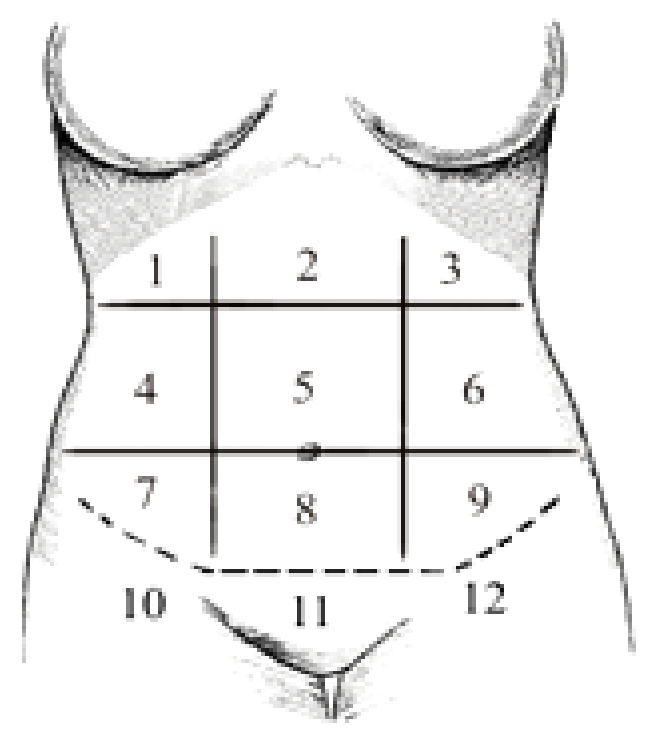

FIGURE 1: Diagram showing the demarcation of the 12 areas of the abdomen.

The lateral limits were the two anterior axillary lines. A transversal line dividing the umbilicus was then marked. The inferior transverse line was determined by the abdominal incision and the superior transversal line was traced on the lateral aspect of the costal margin. The other two vertical lines divide the horizontal line that passes on the umbilical scar in three. Therefore, the 
abdominal skin was divided in 9 regions. Regions 10, 11 and 12 were located below of the surgical scar

The evaluation of sensitivity was carried in the geometric center of the areas 1 to 9 . Areas 10 to 12 were evaluated $1 \mathrm{~cm}$ inferiorly the abdominal incision as shown in FIGURE 2.

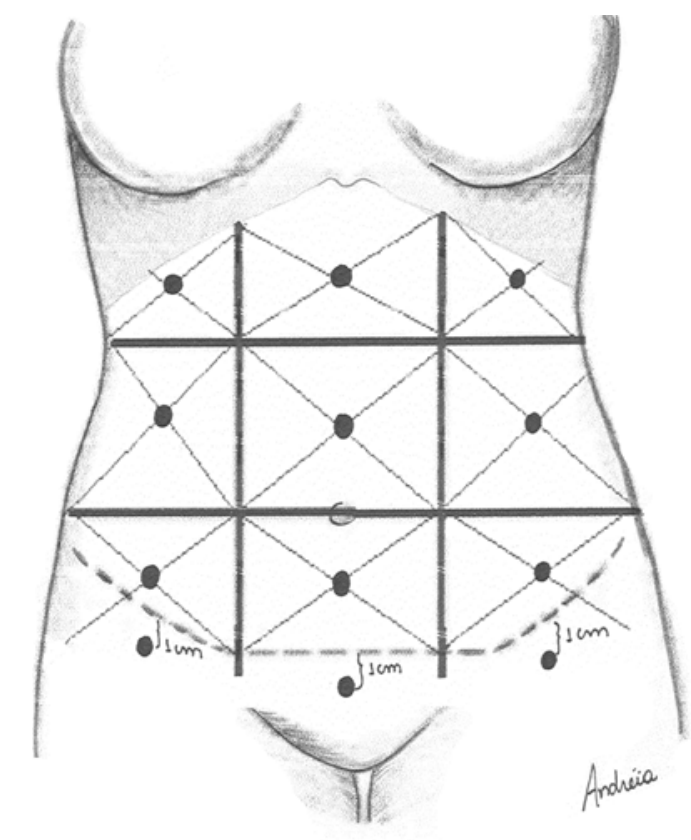

FIGURE 2: Illustration demonstrating the points where the sensibility evaluation was performed

Five different sensorial tests were performed on each area to evaluate superficial touch, superficial pain, pressure, vibration, and temperature.

The abdominal sensibility was measured using several techniques that evaluate distinct receptor and specific nerves fibers. ${ }^{4,11}$ :

a) Superficial touch was tested with the smooth touch of a cotton ball over the skin surface.

b) Superficial pain was evaluated with a sharp object weighting $30 \mathrm{~g}$. This object was placed $1 \mathrm{~cm}$ above the skin surface. Using the gravitational force, this device was released and, as its tip touched the skin, the sensibility to pain was observed. The body of this object was kept hanging by a string.

c) Vibration was evaluated with a tuning fork with a frequency of 435 vibrations per second, placed in contact with the skin.

d) Hot temperature was tested with a glass containing hot water at $60^{\circ} \mathrm{C}$, whereas for cold temperature a glass containing ice was used. 
In all these tests, data was recorded either as positive, if the patient mentioned that she felt the stimulation or negative, if she was unable to feel it. Time for sensorial stimulation was 5 seconds.

Sensibility to pressure was measured using 16 loads weighting from $3.5 \mathrm{~g}$ to $70 \mathrm{~g}$, which exerted pressure from $0.50 \mathrm{gl} / \mathrm{mm}^{2}$ to $9.90 \mathrm{gl} / \mathrm{mm}^{2}$ (TABLE 1).

TABLE 1 - Loads and corresponding pressures used to quantify the threshold of sensitivity to the pressure.

\begin{tabular}{|cccc|}
\hline weight & Mass $(\mathrm{g})$ & Area $(\mathrm{mm} 2)$ & Pressure $(\mathrm{g} / \mathrm{mm} 2)$ \\
\hline \hline 1 & 3,5 & 7,07 & 0,50 \\
2 & 4,0 & 7,07 & 0,57 \\
3 & 4,5 & 7,07 & 0,64 \\
4 & 5,0 & 7,07 & 0,71 \\
5 & 6,0 & 7,07 & 0,85 \\
6 & 8,0 & 7,07 & 1,13 \\
7 & 10,0 & 7,07 & 1,41 \\
8 & 15,0 & 7,07 & 2,12 \\
9 & 20,0 & 7,07 & 2,83 \\
10 & 25,0 & 7,07 & 3,54 \\
11 & 30,0 & 7,07 & 4,24 \\
12 & 35,0 & 7,07 & 4,95 \\
13 & 45,0 & 7,07 & 6,37 \\
14 & 55,0 & 7,07 & 7,78 \\
15 & 65,0 & 7,07 & 9,20 \\
16 & 70,0 & 7,07 & 9,90 \\
\hline
\end{tabular}

The loads were attached to a stick by a string and were placed gently over the skin until there was no tension at the string (FIGURE 3). The patient was submitted to the pressure for 5 seconds $^{14}$ with each weight and the threshold pressure felt by the patient was recorded. 


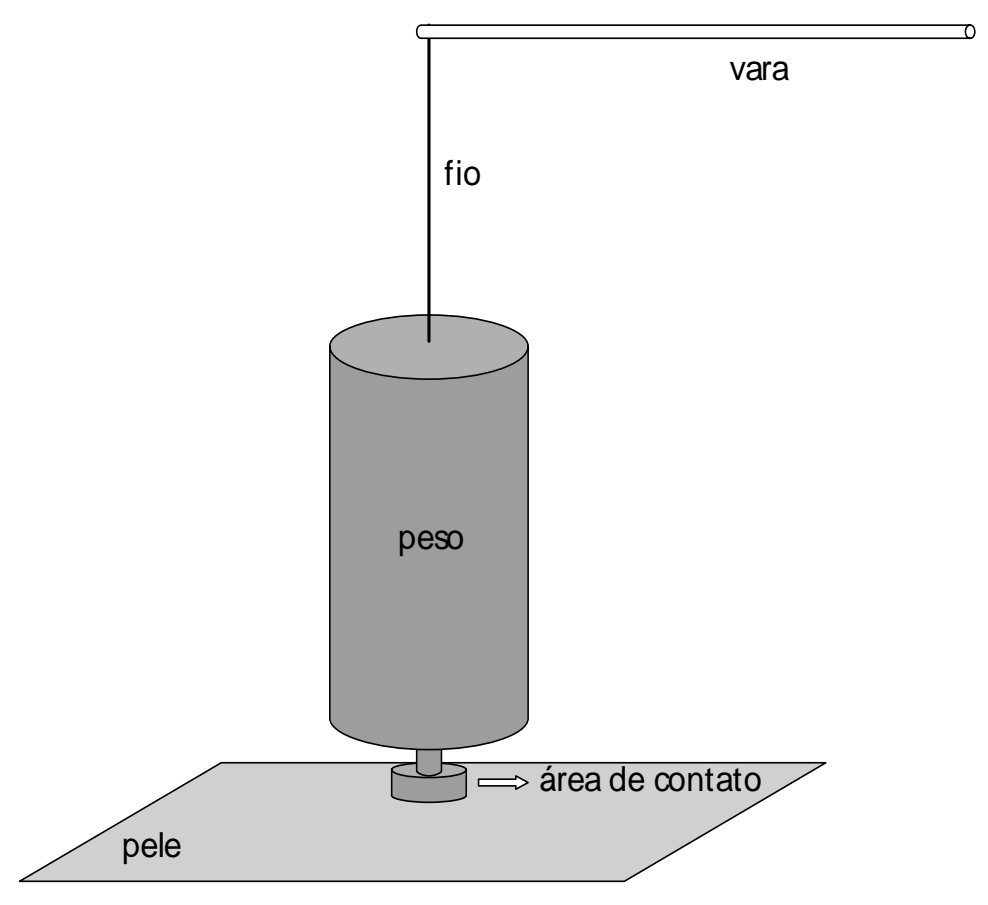

FIGURE 3: Diagram showing the device used to test sensibility to pressure.

\section{Perspectives}

This model can be used to study capsular contracture around breast prosthesis, so that new materials of prosthesis can be tested, as well as in the test of new drugs to avoid capsular contracture.

The described experimental model showed to be feasible to demonstrate the specific alterations of the cutaneous sensitivity of the abdomen after abdominoplasty. It is possible to use this experimental model to study any area of the body before and after surgical procedures.

\section{References}

1.American Society of Plastic and Reconstructive Surgeons (ASPRS) - 2003 Statistical Survey .Available at: URL: http: // www.plasticsurgery.org/ public_education/2003statistics.cfm .

2.Duchateau J, Declety A, Lejour M - Innervation of the rectus abdominis muscle: Implications for Rectus Flaps., Plast Reconstr Surg. 1988;82:223.

3.Farah AB, Nahas FX, Ferreira LM, Mendes J de A, Juliano Y - Sensibility of the abdomen after abdominoplasty. Plast Reconstr Surg. 2004 Aug; 114(2):577-82; discussion 583.

4.Guyton, AC - Tratado de Fisiologia Médica, 8th Ed., Ed. Guanabara Koogan- RJ. pp 420$67,1992$. 
5.Levin S, Pearsall G, Ruderman RJ - Von Frey's method measuring pressure sensibility in the hand: An engineering analysis of the Weinstein-Semmes pressure aesthesiometer. J Hand Surg. 1978;3:211.

6.Liew S, Hunt J, Pennington D - Sensory recovery following free TRAM flap breast reconstruction. Br J.Plast Surg. 1996;49: 210.

7.Ozgenel Ege GY, Ozcan M - Heating-pad Burn as a complication of abdominoplasty. Br J Plast Surg. 2003;56 (1):53-4.

8.Slezak S, Mc Gibbon B, Dellon AL - The sensational transverse rectus abdominis musculocutaneous TRAM flap: Return of Sensibility after TRAM breast reconstruction. Ann Plast Surg. 1992;28:210.

9.Spear S, Hess C - Evaluation of abdominal sensibility after TRAM Flap Breast Reconstruction. Plast Reconstr Surg. 2000;106:1300.

10.Testut E, Latarjet A - Tratado de Anatomia Humana. Salvat Editores,S.A. 1949.

11.Terzis JK, Vincent MP, Wilkins LM, Rutledge K, Deane LM - Breast sensibility: a neurophysiological appraisal in the normal breast. Ann Plast Surg. 1987; 19(4):318-22.

12.Terzis JR - Functional aspects of reinnervation of free skin grafts. Plast Reconstr Surg. 1996;58: $142-55$.

13.Van Uchelen JH, Werker PM, Kon M - Complications of abdominoplasty in 86 patients. Plast Reconstr Surg. 2001 Jun;107 (7):1869-73

14.Van Vliet D, Novak CB, Mackinnon SE - Duration of contact time alters cutaneous pressure threshold measurements Ann Plast Surg. 1993;31:5.

15.Woodward KL, Kenshalo DR - The recovery of sensory function following skin flaps in humans. Plast Reconstr Surg. 1987;79: 428-35.

Farah, AB, Nahas FX, Garcia EB, Ferreira LM. Experimental model for evaluation of the cutaneous sensitivity of the abdome. Acta Cir Bras [serial online] 2004 Vol 19 Edição Especial. Disponível em URL: http://www.scielo.br/acb.

RESUMO - O objetivo deste estudo é relatar e divulgar um modelo experimental para avaliar diversas modalidades de sensibilidade e mapear as áreas da parede abdominal nas quais ocorre diminuição da sensibilidade após abdominoplastia. Dois grupos de pacientes foram estudados: no grupo controle, as paciente não apresentavam incisões abdominais prévias e as pacientes do grupo experimental tinham sido submetidas a abdominoplastia. A avaliação da sensibilidade das pacientes do grupo experimental foi realizada de 12 a 60 meses após a cirurgia. A pele abdominal foi dividida em doze áreas, sendo nove acima e três abaixo da cicatriz da abdominoplastia. As sensibilidades ao toque superficial, dor superficial, ao calor e frio, vibração foram testadas e registradas como positive se a paciente referisse que sentiu o estímulo ou, caso o contrário, negativa. A sensibilidade à pressão foi testada com o uso de diferentes pesos, deste modo, um valor foi obtido quando a paciente sentia a pressão exercida pelo peso. Um teste específico foi utilizado para testar cada modalidade de sensibilidade. O modelo experimental utilizado para testar sensibilidade da pele após abdominoplastia mostrou-se factível em pacientes.

DESCRITORES - Sensibilidade. Abdominoplastia. Parede abdominal. 


\section{Correspondence:}

Fabio Xerfan Nahas

R. Napoleão de Barros, 715

Disciplina de Cirurgia Plástica

São Paulo ,SP. CEP 04024.002

Telefone: (11) 5571.6579

nahas.dcir@epm.br 